\title{
Corrosion behavior of the pre-heated friction stir welded AA2024 alloy reinforced with AA7075 in 3.5\% NaCl solution
}

\author{
Aliaa Abdelfatah ${ }^{1}$, Mohamed Abu-Okail ${ }^{2}$ Lamiaa Z. Mohamed ${ }^{3, *}$ \\ ${ }^{1}$ Corr. and Surface Treatment Lab., Dept. of Metallurgy, Faculty of Engineering, Cairo University, \\ Egypt. \\ ${ }^{2}$ Manufacturing Engineering and Production Technology Department, Modern Academy for \\ Engineering and Technology, P.O. Box 11571, Cairo, Egypt. \\ ${ }^{3}$ Mining, Petroleum, and Metallurgical Engineering Depart. Faculty of Engineering, Cairo University, \\ Egypt. \\ "E-mail: lamiaa.zaky@cu.edu.eg
}

doi: $10.20964 / 2021.01 .44$

Received: 2 September 2020 / Accepted: 7 November 2020 / Published: 30 November 2020

\begin{abstract}
The corrosion resistance of friction stir welded (FSW) AA2024 base material (BM) reinforced with different AA7075 weld material (WM) with different width namely 1.0, 1.5, 2.0, 2.5, and $3.0 \mathrm{~mm}$ as a compensation layer were studied. The effect of pre-weld heat treatment on the corrosion resistance of BM, WM, and heat affected zone (HAZ) were investigated. Both AA2024 and AA7075 alloys were preweld treated under different heat treatment conditions, the first condition was annealed $(\mathrm{O})$, while the second condition was solution heat treated followed by artificial aging (T6). The welded samples were examined for corrosion resistance using potentiodynamic measurements in $3.5 \% \mathrm{NaCl}$ solution for the two heat treatment conditions ( $\mathrm{O}$ and $\mathrm{T} 6$ ). Then, the corroded zones for the two conditions after welding were examined using scanning electron microscopy (SEM), energy dispersion x-ray analysis (EDAX), and mapping of the elemental distribution. It was found that WM-T6 has a higher corrosion rate than WM-O with a uniform corrosion, localized pitting and local galvanic cells formation. After welding, both alloys were highly susceptible to corrosion, and AA2024 alloy had higher susceptibility to corrosion than AA7075 alloy.
\end{abstract}

Keywords: Friction Stir Welding; Corrosion behavior; NaCl Solution; AA2024 Alloy; AA7075 Alloy

\section{$\underline{\text { FULL TEXT }}$}

(C) 2021 The Authors. Published by ESG (www.electrochemsci.org). This article is an open access article distributed under the terms and conditions of the Creative Commons Attribution license (http://creativecommons.org/licenses/by/4.0/). 